\title{
GENETIC VARIABILITY IN JUVENILE CHARACTERS OF PROGENIES OF Apuleia leiocarpa
}

\author{
Queli Cristina Lovatel ${ }^{*}$, Marcio Carlos Navroski², Tamara Rosa Gerber ${ }^{3}$, Luciana Magda de Oliveira ${ }^{4}$, Mariane \\ de Oliveira Pereira ${ }^{5}$, Maiara Fortuna Silveira ${ }^{6}$ \\ 1*Universidade do Estado de Santa Catarina (Udesc), Programa de Pós-Graduação em Engenharia Florestal, Lages, Santa Catarina, Brasil - \\ e-mail: queli.lovate115@gmail.com \\ ${ }^{2}$ Universidade do Estado de Santa Catarina (Udesc), Departamento de Engenharia Florestal, Lages, Santa Catarina, Brasil - e-mail: \\ marcio.navroski@udesc.br \\ ${ }^{3}$ Universidade do Estado de Santa Catarina (Udesc), Lages, Santa Catarina, Brasil - e-mail: tamygerber@hotmail.com \\ ${ }^{4}$ Universidade do Estado de Santa Catarina (Udesc), Departamento de Engenharia Florestal, Lages, Santa Catarina, Brasil - e-mail: \\ luciana.oliveira@udesc.br \\ ${ }^{5}$ Universidade do Estado de Santa Catarina (Udesc), Lages, Santa Catarina, Brasil - e-mail: maripereira.florestal@gmail.com \\ ${ }^{6}$ Universidade do Estado de Santa Catarina (Udesc), Lages, Santa Catarina, Brasil - e-mail: mfortunasilveira@gmail.com
}

Received for publication: 29/09/2019 - Accepted for publication: 19/03/2021

\begin{abstract}
Resumo
Variabilidade genética em caracteres juvenis de progênies de Apuleia leiocarpa. O objetivo desta pesquisa foi quantificar a variabilidade genética em progênies oriundas de matrizes de grápia em populações naturais, para caracteres do crescimento inicial de mudas. Coletou-se sementes de 13 matrizes, de quatro procedências, localizadas nos municípios de Pareci Novo, São José do Sul e Aratiba no RS, e de Seara em SC, assim como os dados das plantas e do local de origem. Foi realizada a biometria em um lote de 100 sementes de cada matriz, e instalado um experimento para avaliar as progênies, em delineamento inteiramente casualizado. Avaliou-se a velocidade de emergência das plântulas e a porcentagem de emergência, o diâmetro do coleto e altura das mudas, assim como a porcentagem final de sobrevivência. Foi encontrada diferença significativa para todas as variáveis observadas para sementes e mudas das matrizes de grápia. Comprimento e largura de sementes demonstraram valores altos para herdabilidade individual no sentido restrito (acima de 0,6), sendo possível utilizar o tamanho da semente para a análise de variabilidade genética entre plantas da espécie, mas não como variável indicativa de qualidade fisiológica e vigor. A análise de correlação indicou que a porcentagem de emergência das plântulas, tem relação com as características da planta matriz (altura e diâmetro). Assim, é adequado o uso das mudas para áreas de restauração florestal, pois apresentam indicativos de diversidade genética.

Palavras-chave: Grápia. Biometria de sementes. Parâmetros genéticos.
\end{abstract}

\begin{abstract}
The objective of this search was to quantify the genetic variability in progenies from grápia mother trees in natural populations, for initial growth characters of the seedlings. Seeds were collected from 13 mother trees, from four origins, located in the municipalities of Pareci Novo, São José do Sul and Aratiba in RS, and Seara in SC, as well as data from plants and place of origin. Biometrics were performed on 100 seeds lot from each mother tree, and an experiment was installed to evaluate progenies in a completely randomized design. It was evaluated the seedling emergence speed and the emergence percentage, the stem diameter and seedlings height, as well as the final survival percentage. A significative difference was found for all variables observed for seeds and seedlings of grápia mother trees. Seed length and width demonstrated high values for individual heritability in the narrow sense (above 0.6), being possible to use the seed size for an analysis of genetic variability between plants of the species, but not as an indicative variable of physiological quality and vigor. The correlation analysis indicated that the seedling emergence percentage is related to the characteristics of the mother plant plant (height and diameter). Thus, the use of seedlings for forest restoration areas is appropriate, as they have indications of genetic diversity.
\end{abstract}

Keywords: Grápia. Seed biometrics. Genetic parameters.

\section{INTRODUCTION}

Apuleia leiocarpa (Vogel) J. F. Macbride $(2 n=26)$ is a species of the Fabaceae family native to Brazil, vulnerable to extinction and known as the queen of forests in the southern region of the country. Popularly called grápia, it grows in the Deciduous Seasonal Forest and reaches large dimensions, with an average height of 25-35 meters and a diameter of 60-90 centimeters (LORENZI, 2008). The species has wood potential due to its dimensions and wood characteristics, with a density of 0.75 to $1.00 \mathrm{~g} \mathrm{~cm}^{-3}$, yellowish color and high durability. It also has apiculture potential, landscaping, medicinal use in areas of forest restoration and use in the tanning industry, considering that its bark reaches up to $24 \%$ of tannins (MARCHIORI, 1997). 
The species has phenological stages at similar times in the southern states, blooming during spring and bearing fruit during summer (FELIPPI et al, 2012). Monoecious plant, it has white or cream colored flowers, masculine and hermaphroditic, predominantly allogamous and with pollination mainly by bees. It has the formation of inflorescences arranged in panicles, the fruit being an ovoid pod, indehiscent and flat, dispersed by wind, having only one seed per fruit, hard, flat and dark brown in color (BACKES; IRGANG, 2002).

The collection of seeds and the production of grápia seedlings is affected by fruit productivity in irregular periods, taking two or more years to obtain a satisfactory harvest (FELIPPI et al., 2012). Brancalion et al. (2009), mention that forest restoration plantations rarely include endangered species, such as grápia, especially due to the difficulty in obtaining seeds and seedlings from these individuals. This variation in seed production is linked to environmental conditions, as well as the variability that exists naturally within populations and between individuals. Within a population, individuals who have favorable genotypes (to that situation) are more likely to perpetuate themselves, having reproductive and adaptive success. Tree species generally have a relatively high degree of genetic variation, when compared to other plants and animal species (HAMRICK; GODT, 1989).

The limitation between the gene flow of plant populations and the selection pressures suffered over time give population groups distinct genetic characteristics, verifying that the genetic variation of the species is associated with their geographic distribution. The gene flow via pollen and seeds has been shown to be associated with the genetic structure of populations of tree species, in which the flight distance of pollinators and dispersers is indicative of the spatial structure of the genetic diversity of populations (KAGEYAMA; LEPSCH-CUNHA, 2001).

Knowledge about the ecology and genetic structure of natural populations of tree species in tropical regions is scarce, but essential to define strategies for their conservation, genetic improvement and sustainable management (KONZEN, 2014; KUBOTA et al., 2015a). Knowing the genetic variability of native species, especially those that are vulnerable to extinction, such as grápia, become of relevance, for the production of seedlings and use of the species in forest restoration (SANT'ANA et al., 2013). Thus, the objective of this study was to quantify the existence of genetic variability of grápia progenies for characters of the initial growth of seedlings.

\section{MATERIAL AND METHODS}

\section{Seed collection area}

The pre-marked progenies of grápia come from the Germplasm Rescue and Bank Formation Project of the Transmission Line (LT) 525 kV Salto Santiago - Itá - Nova Santa Rita. Among the 40 mother trees marked in the project, 13 were used in this study due to the time of collection and production of seeds. For the collection of open pollination seeds, the minimum distance of 100 meters between the trees was respected, in order to minimize the risk of sampling related individuals, seeking genetic and physical-physiological quality of the seeds.

Tabela 1. Altura e diâmetro à altura do peito (DAP) das matrizes de Apuleia leiocarpa (AL) e municípios onde estão localizadas.

Table 1. Height and diameter at breast height (DBH) of Apuleia leiocarpa (AL) mother trees and municipalities where they are located.

\begin{tabular}{cccc}
\hline Mother tree & Height $(\mathbf{m})$ & DBH $(\mathbf{c m})$ & Origin \\
\hline AL 7 & 19.0 & 44.9 & Pareci Novo, RS \\
AL 8 & 15.0 & 32.2 & Pareci Novo, RS \\
AL 9 & 23.0 & 28.3 & São José do Sul, RS \\
AL 14 & 21.0 & 71.0 & São José do Sul, RS \\
AL 29 & 28.0 & 69.4 & São José do Sul, RS \\
AL 30 & 21.0 & 59.8 & São José do Sul, RS \\
AL 31 & 27.0 & 58.3 & São José do Sul, RS \\
AL 32 & 28.0 & 61.8 & São José do Sul, RS \\
AL 33 & 20.0 & 33.1 & São José do Sul, RS \\
AL 34 & 24.0 & 36.6 & São José do Sul, RS \\
AL 36 & 12.0 & 48.4 & São José do Sul, RS \\
AL 37 & 35.0 & 88.5 & Aratiba, RS \\
AL 38 & 37.0 & 82.8 & Seara, SC \\
\hline
\end{tabular}

The mother trees marked in the project are visibly healthy, without attack by pests and mechanical damage to the trunk. Dendrometric data were collected from each mother tree (Table 1), as well as climatic data from the 
municipality they are located: Aratiba (RS) - average temperature $19.4^{\circ} \mathrm{C}$, altitude $423 \mathrm{~m}$ and $1,833 \mathrm{~mm}$ of annual precipitation; Pareci Novo (RS) - average temperature $19.6^{\circ} \mathrm{C}$, altitude $33 \mathrm{~m}$ and $1,418 \mathrm{~mm}$ of annual precipitation; São José do Sul (RS) - average temperature $19.4^{\circ} \mathrm{C}$, altitude $104 \mathrm{~m}$ and 1,442 mm of annual precipitation; Seara (SC) - average temperature $18.8^{\circ} \mathrm{C}$, altitude $551 \mathrm{~m}$ and $1,981 \mathrm{~mm}$ of annual precipitation.

In the areas the mother trees are located soil collection was carried out at a depth of 0-10 cm with a Dutch type auger, composing representative composite samples, in order to carry out the chemical characterization of the soil in each area. For the mother trees AL 07, AL 08, AL 09, AL 14, AL 37 and AL 38, samples were collected close to the individual, with a sample for each mother tree. A sample was carried out in the area where the mother trees AL 29, AL 30, AL 31 and AL 32 are located, and another sample in the area where the mother trees AL 33, AL 34 and AL 36 are located.

\section{Fruit collection and processing}

The collections were carried out in January/2018 and March/2018. The brown colored fruits were collected, stored in plastic bags, identified and taken to the Forest Nursery of the University of the State of Santa Catarina (UDESC), in the municipality of Lages, SC. They remained in a fresh and ventilated place for drying for 20 days. The extraction of seeds occurred manually, opening the pod for their removal. The wilted, attacked by fungi or predated seeds were discarded, and the visually healthy seeds were stored in a paper container, in a refrigerator at $8{ }^{\circ} \mathrm{C}$, until April/2018. According to the Köppen classification, the climate in the municipality of Lages/SC is humid mesothermal with mild summer (Cfb-temperado). The average annual temperature is $15^{\circ} \mathrm{C}$ and the average annual precipitation varies between 1,300 to $1,500 \mathrm{~mm}$.

A sample of 100 seeds from each mother tree was randomly selected for biometric measurements. The measures of length and width of the seeds were obtained with the use of a digital caliper $(0.01 \mathrm{~mm})$.

\section{Dormancy overcome and experimental design}

The grápia seeds were submitted to mechanical scarification manually with sandpaper No. 120, to overcome integumentary dormancy. After this process, the seeds were washed in distilled water and dried on paper towels. In order to standardize and favor the process of soaking in water, it was decided to place the seeds in Gerboxes in a germinator, before sowing in the nursery. The seeds were put in the Gerbox box under Germitest ${ }^{\circledR}$ paper, spaced and then covered with another sheet of Germitest ${ }^{\circledR}$ paper, both moistened with distilled water. The boxes, with 50 seeds each were deposited in a BOD (Biochemical Oxigen Demand) germinator for 30 hours, regulated at $25^{\circ} \mathrm{C}$ and a photoperiod of $12 \mathrm{~h}$. During this period, the humidity of the Germitest ${ }^{\circledR}$ paper was checked every $8 \mathrm{~h}$ to avoid complete drying.

After 30 hours in BOD, the boxes with the seeds were taken to the Forest Nursery - CAV. Sowing was done in $175 \mathrm{~cm}^{3}$ polyethylene tubes, using commercial substrate based on composted pine bark, vermiculite and basic fertilization, enriched with $6 \mathrm{~g} \mathrm{~L}^{-1}$ of controlled release fertilizer (15-09-12, $\left.5 \mathrm{M}\right)$. The seeds were put on the substrate and covered with $15 \mathrm{ml}$ of medium-sized expanded vermiculite. All seeds received equal coverage to not influence the emergence and evaluation process. The grids with the tubes remained in a greenhouse with a temperature of 20 to $30^{\circ} \mathrm{C}$, irrigation by micro sprinkler with four irrigations a day for 10 minutes, reduced to 3 times a day in the winter period for 5 minutes. The experimental design was completely randomized with eight replications of 17 plants each, with 13 treatments (mother trees).

In addition to seed biometrics, it was evaluated as well the seedling emergence speed, emergence percentage, seed diameter and seedling height and the final percentage of survival was. The emergence evaluation was performed daily, considering as emerged seedlings those that presented the cotyledonary loop above the substrate.

The calculation of the emergence speed index (ESI) was performed according to the formula proposed by Maguire (1962):

$$
\mathrm{ESI}=\left(\frac{\mathrm{E} 1}{\mathrm{~N} 1}\right)+\left(\frac{\mathrm{E} 2}{\mathrm{~N} 2}\right)+\cdots+\left(\frac{\mathrm{En}}{\mathrm{Nn}}\right)
$$

As for: $\mathrm{ESI}=$ emergence speed index; $\mathrm{E}=$ number of seedlings emerged each day, and; $\mathrm{N}=$ number of days elapsed from sowing to the last germination count.

The seedling emergence percentage was evaluated in conjuction with the last emergence count, on the 18th after sowing. Normal seedlings were considered for this calculation. At 210 days, the height and diameter at neck height of the seedlings was measured. For height, a $60 \mathrm{~cm}$ ruler was used, and for the diameter, a digital caliper $(0.01 \mathrm{~mm})$. Afterwards, the height/diameter at the neck height $(\mathrm{H} / \mathrm{D})$ and the percentage of seedling survival were calculated. 


\section{Statistical analysis}

After analyzing the data of the observed variables, confirming normality using the Kolmogorov-Smirnov test $(p>0.05)$ and homogeneity using the Bartlett test $(p>0.05)$, the data were submitted to analysis of ANOVA variance and when significant, the Scott-Knott averages test $(p<0.05)$ was performed, with the aid of the Sisvar statistical software.

Pearson's correlation analysis was performed for the variables: mother tree height, mother tree diameter, average temperature and soil characteristics ( $\mathrm{pH}, \mathrm{Ca}, \mathrm{Mg}, \mathrm{Al}, \mathrm{MO}, \mathrm{P}, \mathrm{K}$ and $\mathrm{CEC}$ ) of the mother tree location, seed width and length, ESI, percentage of emergence, percentage of survival, diameter at the neck height and height of seedlings.

The genetic analysis was performed with the aid of the software Statistical System and Computerized Genetic Selection (SELEGEN) (RESENDE, 2007). For the seed length and width variables, the statistical model used was: $y=\mathrm{X} u+\mathrm{Z} a+e$, as $y$ is the data vector, $u$ is the scalar referring to the general mean (fixed effect), $a$ is the vector of the effects individual genetic additives (assumed to be random), $e$ is the vector of errors or residues (random).

For the estimation of the genetic parameters of the variables ESI, percentage of emergence, diameter of the collection and height of the seedlings, the statistical model used was: $y=X u+Z a+W p+e$, as $y$ is the data vector, $u$ is the general average effect (fixed), $a$ is the vector of the individual additive genetic effects (assumed to be random), $p$ is the vector of the parcel effects, $e$ is the vector of errors or residues (random). In both models, the capital letters represent the incidence matrices for the referred effects.

The mixed model equations for BLUP prediction of individual genetic values are equivalent to:

$$
\left[\begin{array}{cccc}
X^{\prime} X & X^{\prime} Z & Z^{\prime} W & X^{\prime} T \\
Z^{\prime} X & Z^{\prime} Z+I \lambda_{1} & Z^{\prime} W & Z^{\prime} T \\
W^{\prime} X & W^{\prime} Z & W^{\prime} W+I \lambda_{2} & W^{\prime} T \\
T^{\prime} X & T^{\prime} Z & T^{\prime} W & T^{\prime} T+I \lambda_{3}
\end{array}\right] \times\left[\begin{array}{l}
r \\
a \\
p \\
b
\end{array}\right]=\left[\begin{array}{c}
X^{\prime} y \\
Z^{\prime} y \\
W^{\prime} y \\
T^{\prime} y
\end{array}\right]
$$

As for:

$$
\lambda_{1}=\frac{\widehat{\sigma}_{e}^{2}}{\widehat{\sigma}_{a}^{2}}=\frac{1-\mathrm{h}^{2}-\mathrm{C}_{\mathrm{p}}^{2}-\mathrm{C}_{\mathrm{dic}}^{2}}{\mathrm{~h}^{2}} ; \lambda_{2}=\frac{\widehat{\sigma}_{e}^{2}}{\widehat{\sigma}_{p}^{2}}=\frac{1-\mathrm{h}^{2}-\mathrm{C}_{\mathrm{p}}^{2}-\mathrm{C}_{\mathrm{dic}}^{2}}{\mathrm{C}_{\mathrm{p}}^{2}} ; \lambda_{3}=\frac{\widehat{\sigma}_{e}^{2}}{\widehat{\sigma}_{\text {dic }}^{2}}=\frac{1-\mathrm{h}^{2}-\mathrm{C}_{\mathrm{p}}^{2}-\mathrm{C}_{\mathrm{dic}}^{2}}{\mathrm{C}_{\mathrm{dic}}^{2}}
$$

$\mathrm{h}^{2}=\hat{\sigma}_{a}^{2} / \hat{\sigma}_{a}^{2}+\hat{\sigma}_{p}^{2}+\hat{\sigma}_{d i c}^{2}+\hat{\sigma}_{e}^{2}$ is individual heritability in the narrow sense;

$\mathrm{C}_{\mathrm{p}}^{2}=\hat{\sigma}_{p}^{2} / \hat{\sigma}_{a}^{2}+\hat{\sigma}_{a}^{2}+\hat{\sigma}_{d i c}^{2}+\hat{\sigma}_{e}^{2}$ is the correlation, due to the common environment of the plot; and

$\mathrm{C}_{\mathrm{dic}}^{2}=\hat{\sigma}_{\text {dic }}^{2} / \hat{\sigma}_{a}^{2}+\hat{\sigma}_{p}^{2}+\hat{\sigma}_{\text {dic }}^{2}+\sigma_{\mathrm{e}}^{2}$ is the correlation, due to the common environment of the completely randomized design.

In order to detect the genetic variability of the characters in the population, the index $(\hat{b})$ was calculated, according to the formula: $\hat{b}=C V_{g i} C V_{e}$, which it represents the ratio between the coefficient of genetic variation and the coefficient of experimental variation, not influenced by the character average.

\section{RESULTS}

For the seeds biometrics it was possible to observe that the seeds had different sizes (Table 2). There was a greater difference between seeds width than between the length. The two mother trees with the largest seeds were not the longest, just as the two of the longest were not the largest. The mother tree AL 33 presented the largest seed size, considering the dimensions of width and length, followed by the mother trees AL 38, AL 34, AL 07 and AL 37. The smallest seeds were from the mother trees AL 32, AL 30, AL 29 and AL 09.

Tabela 2. Variáveis analisadas para sementes (LS, CS, IVE e E) e para as mudas (SB, H, DC, H/D) de Apuleia leiocarpa.

Table 2. Variables analyzed from seeds (SW, SL, ESI and E) and seedlings (SV, H, ND, H/D) of Apuleia leiocarpa. 


\begin{tabular}{|c|c|c|c|c|c|c|c|c|}
\hline M. Tree & SW (mm) & SL (mm) & ESI & E $(\%)$ & SV (\%) & H (cm) & ND (mm) & H/D \\
\hline AL 9 & $5.56 \mathrm{f}$ & $7.11 \mathrm{~d}$ & $1.29 \mathrm{a}$ & $93 \mathrm{a}$ & $47 \mathrm{a}$ & $9.69 \mathrm{~b}$ & $1.75 \mathrm{~b}$ & $5.53 \mathrm{~b}$ \\
\hline AL 8 & $6.55 \mathrm{~d}$ & $7.56 \mathrm{c}$ & $1.60 \mathrm{a}$ & 84 a & $61 \mathrm{a}$ & $11.12 \mathrm{a}$ & $1.96 \mathrm{a}$ & $5.68 \mathrm{a}$ \\
\hline AL 36 & $7.04 \mathrm{~b}$ & $7.56 \mathrm{c}$ & $1.07 \mathrm{~b}$ & $69 \mathrm{~b}$ & $60 \mathrm{a}$ & $10.54 \mathrm{~b}$ & $1.99 \mathrm{a}$ & $5.33 \mathrm{~b}$ \\
\hline AL 32 & $6.27 \mathrm{e}$ & $7.53 \mathrm{c}$ & $1.37 \mathrm{a}$ & $65 \mathrm{~b}$ & 55 a & $10.00 \mathrm{~b}$ & $1.84 \mathrm{~b}$ & $5.48 \mathrm{~b}$ \\
\hline AL 29 & $6.13 \mathrm{e}$ & $7.64 \mathrm{c}$ & $0.99 \mathrm{~b}$ & $65 \mathrm{~b}$ & 59 a & $10.18 \mathrm{~b}$ & $1.84 \mathrm{~b}$ & $5.52 \mathrm{~b}$ \\
\hline AL 33 & $7.39 \mathrm{a}$ & $7.89 \mathrm{~b}$ & $1.20 \mathrm{a}$ & $65 \mathrm{~b}$ & $52 \mathrm{a}$ & $12.36 \mathrm{a}$ & $2.02 \mathrm{a}$ & $6.15 \mathrm{a}$ \\
\hline AL 14 & $6.28 \mathrm{e}$ & $7.78 \mathrm{~b}$ & $0.92 \mathrm{~b}$ & $63 \mathrm{~b}$ & 48 a & $9.65 \mathrm{~b}$ & $1.76 \mathrm{~b}$ & $5.49 \mathrm{~b}$ \\
\hline AL 31 & $6.51 \mathrm{~d}$ & $7.78 \mathrm{~b}$ & $1.06 \mathrm{~b}$ & $62 \mathrm{~b}$ & 56 a & $11.12 \mathrm{a}$ & $2.05 \mathrm{a}$ & $5.49 \mathrm{~b}$ \\
\hline AL 38 & $6.89 \mathrm{~b}$ & $8.19 \mathrm{a}$ & $0.80 \mathrm{~b}$ & $61 \mathrm{~b}$ & 49 a & $9.76 \mathrm{~b}$ & $2.00 \mathrm{a}$ & $4.68 \mathrm{c}$ \\
\hline AL 34 & $6.70 \mathrm{c}$ & $8.13 \mathrm{a}$ & $0.91 \mathrm{~b}$ & $57 \mathrm{~b}$ & $60 \mathrm{a}$ & $11.93 \mathrm{a}$ & $2.03 \mathrm{a}$ & $5.87 \mathrm{a}$ \\
\hline AL 30 & $6.26 \mathrm{e}$ & $7.68 \mathrm{c}$ & $1.05 \mathrm{~b}$ & $57 \mathrm{~b}$ & 48 a & $10.47 \mathrm{~b}$ & $1.94 \mathrm{a}$ & $5.41 \mathrm{~b}$ \\
\hline AL 7 & $7.24 \mathrm{a}$ & $7.45 \mathrm{c}$ & $0.56 \mathrm{~b}$ & $38 \mathrm{c}$ & 38 a & $11.30 \mathrm{a}$ & $1.90 \mathrm{~b}$ & 5.89 a \\
\hline \multirow[t]{3}{*}{ AL 37} & $6.79 \mathrm{c}$ & $7.93 \mathrm{~b}$ & $0.57 \quad b$ & $32 \mathrm{c}$ & $42 \mathrm{a}$ & $9.28 \mathrm{~b}$ & $1.86 \mathrm{~b}$ & $5.03 \mathrm{c}$ \\
\hline & Aver.: 6.58 & Aver.: 7.71 & Aver.: 1.03 & Aver.: 62.5 & Aver.: 51.79 & Aver.: 10.61 & Aver.: 1.92 & Aver.: 5.54 \\
\hline & CV \% 4.18 & CV\% 4.67 & CV\% 41.33 & CV\% 27.9 & CV\% 38.72 & CV\% 25.83 & CV\% 20.22 & CV\% 18.10 \\
\hline
\end{tabular}

*Data followed by the same lowercase letter in the column do not differ statistically from each other by the Scott-Knott Test (p <0.05). As for: SW - seed width, SL - seed length, ESI - emergence speed index, E - emergence, SV - survival, H - seedling height, ND - seedling neck diameter (diameter at neck height), H/D - height and diameter ratio.

The emergence of grápia seedlings started on the 5th day after sowing (counted from the moment the seeds were placed in the BOD germinator). The evaluation and counting of the emergence occurred every day until stabilization, a fact stated on the 18th day after sowing. The largest number of seedlings emerged was observed between the 8th and the 10th day. For the calculation of the ESI, data from the 5th to the 10th day were used. This limitation in the use of the evaluation days was adopted in order not to favor the results for any mother tree.

Four mother trees had a higher ESI and differed statistically from the others (Table 2). The highest ESI was assigned to mother tree AL 08, followed by AL 32, AL 09 and AL 33. The emergence presented variation between mother trees (Table 2). The seeds of AL 09 and AL 08 stood out from the others with $93 \%$ and $84 \%$ emergence, respectively. These two mother trees were also among the four with the highest recorded ESI. The lowest indices were with AL 07 and AL 37 with $38 \%$ and $32 \%$ of emergence, respectively, coinciding with the lowest rates of ESI among the thirteen mother trees evaluated. The general average of emergence was $62 \%$.

For the height, diameter at the neck height and percentage of survival of the seedlings there were also differences between the mother trees (Table 2). The observed values for survival were considered low, due to the loss of many seedlings throughout the experiment. The percentage of survival of the seedlings did not differ statistically between the mother trees (Table 2). The general survival average was $52 \%$, with a decrease in seedlings until the evaluation ( 7 months). For height and diameter at the neck height, it can be observed that the values found are considered low for seedlings of 7 months old of the species, as the average height was $10.6 \mathrm{~cm}$ and the diameter was $1.92 \mathrm{~mm}$. The seedlings of the mother trees that presented the greatest growth (height and ND) were: AL 33, AL 34, AL 07, AL 31 and AL 08. Among these, only AL 08 showed a higher percentage of emergence than the others, while the seeds of AL 07 revealed low seedling emergence power. The seeds of the other mother trees obtained average rates of emergence.

\section{Correlation analysis}

With Person's correlation analysis (Table 3), it was noticed for seed biometry that the width did not show any correlation greater than 0.5 . The seeds length, on the other hand, presented a significant and positive correlation close to 0.5 with the height and diameter of the mother trees and negative with the temperature of the collection areas. The width and length of the seeds also showed values close to 0.5. The emergence and the ESI presented a strong correlation (0.85), confirming what was observed in the averages test, with the highest rates of ESI coincided with the highest percentages of emergence. The emergence also revealed a negative correlation close to 0.5 in relation to the length and width of seeds.

The diameter and height of the mother trees correlate with each other and furthermore with most of the soil nutrients. The height of the cultivated seedlings showed 0.69 correlation with the phosphorus $(\mathrm{P})$ from the place of origin of the mother trees, just as the seedlings survival had a correlation of 0.64 with the aluminum $(\mathrm{Al})$ from the collection area. 
Tabela 3. Resultado da correlação de Pearson para as 18 variáveis analisadas, nas progênies de Apuleia leiocarpa. Table 3. Pearson correlation results for the 18 variables analyzed in the progenies of Apuleia leiocarpa.

\begin{tabular}{|c|c|c|c|c|c|c|c|c|c|c|c|c|c|c|c|c|c|c|}
\hline & H & DBH & $\mathbf{T} a$ & pH & $\mathbf{C a}$ & Mg & Al & MO & $\mathbf{P}$ & K & CEC & SW & SL & ESI & $\mathbf{E}$ & SV & Ha & ND $a$ \\
\hline H & 1.00 & 0.72 & $0.65^{*}$ & 0.10 & 0.20 & 0.02 & 0.15 & 0.57 & 0.80 & 0.08 & 0.32 & 0.13 & 0.49 & 0.42 & 0.37 & 0.29 & 0.47 & 0.09 \\
\hline DBH & & 1.00 & 0.52 & 0.09 & 0.10 & 0.03 & 0.12 & 0.47 & 0.70 & 0.04 & 0.25 & 0.01 & 0.46 & 0.55 & 0.55 & 0.30 & 0.67 & 0.18 \\
\hline $\mathbf{T} a$ & & & 1.00 & 0.06 & 0.14 & 0.02 & 0.16 & 0.57 & 0.60 & 0.02 & 0.16 & 0.05 & 0.56 & 0.23 & 0.01 & 0.05 & 0.34 & 0.19 \\
\hline pH & & & & 1.00 & 0.95 & 0.92 & 0.95 & 0.69 & 0.08 & 0.98 & 0.86 & 0.04 & 0.20 & $\mathbf{0 . 4 3}$ & 0.14 & 0.73 & 0.40 & 0.53 \\
\hline $\mathrm{Ca}$ & & & & & 1.00 & 0.93 & 0.88 & 0.69 & 0.20 & 0.94 & 0.95 & 0.26 & 0.29 & 0.35 & 0.00 & 0.72 & 0.52 & 0.63 \\
\hline $\mathbf{M g}$ & & & & & & 1.00 & 0.80 & 0.49 & 0.06 & 0.90 & 0.89 & 0.25 & 0.32 & $\mathbf{0 . 3 0}$ & 0.02 & 0.64 & 0.41 & 0.68 \\
\hline Al & & & & & & & 1.00 & 0.79 & 0.20 & 0.89 & 0.73 & 0.08 & 0.04 & 0.39 & 0.13 & 0.64 & 0.37 & 0.39 \\
\hline MO & & & & & & & & 1.00 & 0.54 & 0.59 & 0.58 & 0.18 & 0.33 & 0.60 & 0.35 & 0.60 & 0.50 & 0.18 \\
\hline $\mathbf{P}$ & & & & & & & & & 1.00 & 0.03 & 0.32 & 0.30 & 0.29 & 0.12 & 0.09 & 0.18 & 0.69 & 0.15 \\
\hline $\mathbf{K}$ & & & & & & & & & & 1.00 & 0.87 & 0.07 & 0.32 & $\mathbf{0 . 4 3}$ & 0.15 & 0.77 & 0.36 & 0.55 \\
\hline CEC & & & & & & & & & & & 1.00 & 0.45 & 0.34 & 0.32 & 0.01 & 0.72 & 0.65 & 0.73 \\
\hline SW & & & & & & & & & & & & 1.00 & 0.48 & 0.39 & 0.54 & 0.10 & 0.54 & 0.64 \\
\hline SL & & & & & & & & & & & & & 1.00 & 0.41 & 0.47 & 0.09 & 0.17 & 0.56 \\
\hline ESI & & & & & & & & & & & & & & & 0.85 & 0.63 & 0.18 & 0.01 \\
\hline $\mathbf{E}$ & & & & & & & & & & & & & & & 1.00 & 0.55 & 0.01 & 0.14 \\
\hline SV & & & & & & & & & & & & & & & & 1.00 & 0.33 & 0.40 \\
\hline $\mathbf{H} \boldsymbol{a}$ & & & & & & & & & & & & & & & & & 1.00 & 0.69 \\
\hline $\mathrm{ND} a$ & & & & & & & & & & & & & & & & & & 1.00 \\
\hline
\end{tabular}

As for: $\mathrm{H}$ - mother's tree height; $\mathrm{DBH}$ - diameter at breast height; $\mathrm{T} a$-average temperature of the mother's tree location; $\mathrm{pH}, \mathrm{Ca}, \mathrm{Mg}, \mathrm{Al}$, MO, P, K, CEC - chemical soil characteristics of mother's tree location; SW - seeds width; SL - seeds length; ESI - emergence speed index; $\mathrm{E}$ - emergence percentage; SV - survival percentage; $\mathrm{H} a$ - average seedlings height; $\mathrm{ND} a$-average seedling neck diameter (diameter at the neck height).

* Numbers highlighted in bold present negative correlation.

\section{Genetic parameters estimative}

Among the characters analyzed (Table 4), seed length $(S L)$ and seed width $(S W)$ presented the highest values for individual heritability in the strict sense $\left(h^{2} a\right)$ of 0.67 and 0.69 , respectively, considered high values.

Tabela 4. Componentes da variância para as variáveis CS (comprimento de sementes), LS (largura de sementes), $I V E$ (índice de velocidade de emergência), $E$ (emergência), $D C$ (diâmetro do coleto) e $H$ (altura das mudas) para as sementes e mudas de Apuleia leiocarpa.

Table 4. Variation components for variables $S L$ (seed length), $S W$ (seed width), ESI (emergence speed index), $E$ (emergence), $N D$ (neck diameter) and $H$ (seedling height) for seeds and seedlings of Apuleia leiocarpa.

\begin{tabular}{ccccccc}
\hline Components & SL $(\mathbf{m m})$ & $\mathbf{S W}(\mathbf{m m})$ & ESI & E(\%) & ND $(\mathbf{m m})$ & H $(\mathbf{c m})$ \\
\hline$\hat{\sigma}_{a}^{2}$ & 0.31 & 0.97 & 0.05 & 133.72 & 0.03 & 2.72 \\
$\hat{\sigma}_{\text {parc }}^{2}$ & - & - & 0.04 & 175.84 & 0.02 & 0.86 \\
$\hat{\sigma}_{e}^{2}$ & 0.15 & 0.40 & 0.12 & 201.94 & 0.11 & 4.79 \\
$\hat{\sigma}_{f i}^{2}$ & 0.47 & 0.57 & 0.22 & 511.50 & 0.16 & 8.38 \\
$h^{2}$ & $0.67 \pm 0.12$ & $0.69 \pm 0.20$ & $0.24 \pm 0.27$ & $0.26 \pm 0.28$ & $0.18 \pm 0.09$ & $0.32 \pm 0.13$ \\
$h^{2}{ }_{\text {aj }}$ & - & - & 0.3054 & 0.3983 & 0.2165 & 0.3625 \\
$C^{2}$ parc & - & - & 0.19 & 0.34 & 0.14 & 0.1 \\
$h^{2}$ ad & 0.6102 & 2.2133 & 0.2480 & 0.3318 & 0.1717 & 0.2990 \\
$C V_{\text {gi }}(\%)$ & 7.28 & 14.93 & 22.08 & 18.51 & 9.05 & 15.74 \\
$C V_{\text {gp }}(\%)$ & 3.64 & 7.46 & 11.04 & 9.26 & 4.53 & 7.87 \\
$C V_{e}(\%)$ & 8.06 & 8.69 & 23.80 & 23.40 & 9.46 & 11.09 \\
$\hat{b}$ & 0.90 & 1.72 & 0.93 & 0.79 & 0.96 & 1.42 \\
General average & 7.71 & 6.59 & 1.05 & 62 & 1.92 & 10.61 \\
\hline As
\end{tabular}

As for: $\hat{\sigma}_{a}^{2}=$ additive genetic variance; $\hat{\sigma}_{\text {parc }}^{2}=$ environmental variance between plots; $\hat{\sigma}_{e}^{2}=$ residual variance (environmental + non additive); $\hat{\sigma}_{f i}^{2}=$ individual phenotypic variance; $h_{a}^{2}=$ individual heritability in the strict sense; $h_{a j}^{2}=$ individual heritability in the strict sense, adjusted for the plot effects; $C_{\text {parc }}^{2}=$ coefficient for determining the plot effects; $h_{a d}^{2}=$ additive heritability within the plot; $C V_{g i}(\%)=$ individual additive genetic coefficient of variation; $C V_{g p}(\%)=$ genotypic coefficient of variation between progenies; $C V_{e}(\%)=$ residual coefficient of variation; $\hat{b}=$ ratio between the genetic coefficient of variation and the experimental coefficient of variation. 
$S W$, in relation to $S L$, presented higher values of important genetic parameter estimates such as additive genetic variance $\left(\sigma^{\wedge}{ }_{a}\right)$, individual phenotypic variance $\left(\hat{\sigma}_{f i}^{2}\right)$, individual additive genetic coefficient of variation $\left(C V_{g i}(\%)\right)$ and genotypic coefficient of variation between progenies $\left(C V_{g p}(\%)\right)$. The emergence speed index (ESI) and the emergence percentage (E) showed heritability close to 0.25 (low) and individual additive genetic coefficient of variation $\left(C V_{g i}(\%)\right)$ between 18.51 and 22.08. These two variables presented a and genotypic coefficient of variation between progenies $\left(C V_{g p}(\%)\right)$ of approximately $10 \%$. The values of the residual coefficient of variation $\left(C V_{e}(\%)\right)$ for these variables were higher than $20 \%$. The $\hat{b}$ index, $S W$ and $H$ obtained values greater than 1 .

In relation to the variables diameter at the neck diameter $(N D)$ and height of the seedlings $(H)$ there was a greater heritability for $H(0.32)$ as well as for the additive genetic variance $\left(\hat{\sigma}_{a}^{2}\right)$, individual phenotypic variance $\left(\hat{\sigma}_{f i}^{2}\right)$, individual additive genetic coefficient of variation $\left(C V_{g i}(\%)\right)$ and genotypic coefficient of variation between progenies $\left(C V_{g p}(\%)\right)$

\section{DISCUSSION}

Grápia seeds showed variation in size between mother trees. The seeds size is related to the amount of reserves, influencing germination and emergence (PÁDUA et al., 2010). The variation found in terms of size probably happened due to genetic variability, since the heritability values for $S L$ and $S W$ were high, above 0.6 , manifesting a high genetic effect for this character. The fruits and seeds size can vary between plants of the same species, between reproductive years and on the same plant. The difference in the size for both fruits and seeds between individuals, in the same population, constitutes one of the most important sources of variability available (SANTOS et al., 2009), also helping in the study of dispersion and dispersing agents. The observed values were between 0.71 and $0.79 \mathrm{~cm}$ for $S L$ and 0.50 to $0.70 \mathrm{~cm}$ for $S W$, smaller than other experiments in which the seeds were 1.2 to $2.1 \mathrm{~cm}$ long and 0.60 to $0.95 \mathrm{~cm}$ wide (FELIPPI et al., 2012).

Searches consider that the classification of seeds by size and weight has the objective of standardizing the speed of emergence (PÁDUA et al., 2010). In this study, the greatest results for ESI were observed in the mother trees AL 08, AL 32 and AL 09; being attributed the seeds considered small by biometrics. The correlation of ESI with length and width of seed was low and negative ( -0.41 and -0.39 respectively), suggesting that the size of the seed has little influence on ESI and germination. This result limits the use of seed size as an indicator of physiological seed quality in grápia. Similar results were obtained by Santos et al. (2009), who found no influence on the size of the seeds of Tabebuia chrysotricha Mart. Ex. A. on the germination test characteristics.

With the different rates of emergence, the average among all mother trees was 62\%. Felippi et al. (2012) obtained a final percentage of emerged seeds ranging from $26.38 \%$ to $87.54 \%$ without using any methods to overcome dormancy, and Nicoloso et al. (1997) found a germination potential from $90 \%$ to $100 \%$ using sulfuric acid. The results obtained suggest that the potential for germination as well as vigor is associated with the mother tree individually and that overcoming dormancy is important for homogenization of germination, mainly for the production of seedlings from a several mother trees lot.

For the production of seedlings of the species it is important to select mother trees that produce seeds with high germination power, considering that this factor can be quite variable. The mother tree AL 37 has a high height and a large diameter when compared to the others and can be considered an older plant, justifying the low germination rate of the seeds. The correlation found between emergence and DBH of the mother trees was negative, of -0.55 , confirming this hypothesis. Still considering the diameter of the plants, the seeds of the mother trees AL 09 and AL 08, which had the highest germination rates, came from mother trees of smaller diameters, possibly the youngest plants and with greater vegetative vigor. Dendrochronology studies are important to confirm the results found.

As for survival, the mortality rate of the plants was high, even with some mother trees showing a greater tolerance to adverse factors. What can be used as a guide for future experiments with grápia seedlings is the care with irrigation, especially in winter and with high relative humidity. Irrigation is one of the key points in the production of seedlings, and the excess of irrigation can cause mortality in many native species, which often have low water demand (THEBALDI et al., 2016). The temperature inside the greenhouse can also damage the leaves. High mortality of seedlings of the species was observed in the winter period (June and July) due to the amount of irrigation received, standard for the other species of the Forest Nursery. Because it is a species found in Santa Catarina in the Seasonal Deciduous Forest (FONTANA; SEVEGNANI, 2012), low temperatures probably contributed to mortality. The first symptoms of mortality appeared on the leaves, which turned a light green color and later on the complete fall of the seedlings. After mortality, the seedlings started to receive irrigation less frequently.

The height and diameter at the neck height evaluation showed a low growth of seedlings. In other studies with the species, four months after germination, the average height was $18 \mathrm{~cm}$ and the diameter at the neck

FLORESTA, Curitiba, PR, v. 51, n. 3, p. 547-556, jul/set 2021

Lovatel, Q. C. et.al.

ISSN eletrônico 1982-4688

DOI: 10.5380/rf.v51 i3. 69454 
height was around $3 \mathrm{~mm}$ (FELIPPI et al., 2012) and $10 \mathrm{~cm}$ at 100 days (NICOLOSO et al., 1997). However, this difference in growth rates may be due to the climatic conditions where each study was carried out and at the time when sowing occurred. In this experiment, sowing was carried out in the month of April and in the second month the plants were already subjected to winter conditions, when growth is generally slower.

Regarding the genetic parameters, the size of the seeds proved to be an efficient criterion to verify the genetic diversity among mother trees. Heritability was high for both evaluated criteria (width and length). Heritabilities are classified according to the interpretation proposed by Resende (1995) from 0.01 to 0.15 as low; 0.15 to 0.50 are medians and; above 0.50 high. Based on this classification, the emergence speed index (ESI) and emergency speed (E \%), presented median heritabilities ( 0.24 and 0.26 respectively). These variations are important indicators of genetic variability to be explored in breeding programs, enabling the selection of promising materials, because with the knowledge of the heritability coefficient of a trait and the study of the population to be improved it is possible to estimate the expected genetic gain with the selection even before it is carried out (ROSADO et al., 2010).

It should also be noted that the heritability coefficient in the narrow sense reflects how much of the phenotypic variation observed in a quantitative character is inheritable due to the effects of additive genes, transferred from parental individuals to their descendants (COSTA et al., 2010). It is an important genetic parameter because it allows knowing the potential or the power to change the mean of a character in a population by artificial selection (KUBOTA et al., 2015b).

As for the genetic parameters in relation to the variables diameter at the neck height $(N D)$ and height of the seedlings $(H), H$ was shown to be a variable that has greater facility for selecting superior and contrasting materials. Generally, the heritability values for quantitative characteristics such as height and diameter are between 0.2 and 0.3 . However, it can present high variation, mainly in younger stages of plant development, as observed in the study by Menegatti et al. (2016), who found average heritability values of Mimosa scabrella Benth. progenies at 12 months of age ranging from 0.11 to 0.54 for the $\mathrm{DBH}$ character and from 0.01 to 0.82 for the height character.

In addition to having greater heritability, the height of the seedlings $(H)$ presented a higher genetic coefficient of variation, which favors selection. The genetic coefficients of variation, both at the individual level $\left(C V_{g i}(\%)\right)$ and at the progeny level $\left(C V_{g p}(\%)\right)$ are admitted as essential indicators of the existing variation, allowing to estimate genetic gains in provenance and progeny tests (AGUIAR et al., 2010). According to Sebbenn et al. (1998) a coefficient of genetic variation greater than $7 \%$ is considered high. Thus, all parameters of seed biometrics, germination and initial growth of seedlings can be used as indicative of success in the selection of genetic materials from grápia mother trees.

The values of the experimental coefficient of variation $\left(\mathrm{CV}_{e}(\%)\right)$ were considered median for all evaluated variables, with values between $8.06 \%$ and $11.09 \%$, with the exception of ESI and E, which presented $(>20 \%)$. However, in general, the experimental control was satisfactory, and one can expect good precision in the estimates of genetic parameters for the evaluated characters. Only the variables SW (1.72) and $\mathrm{H}(1.42)$ presented values of the index $\hat{b}$, greater than 1 . The use of these characters may result in greater gains in the selection, since the values of the index greater than 1 are due to their own high genetic variance, probably little influenced by the environment, indicating great possibility and success in the selection (VENCOVSKY, 1978).

Early characters such as those used in this study can serve as indicators of genetic diversity (KUBOTA et al., 2015b). The relative contribution of each character to the genetic divergence is of great importance to identify the characters with the greatest contribution and assist in the disposal of those with the least contribution. Therefore, in order to predict genetic gains with selection, it is essential to estimate genetic parameters (BERTI $e t$ al, 2011).

Regarding the collection of seeds, the definition of zones for the collection and use of seeds can be carried out based on biophysical information (altitude, latitude, climate, soil, etc.), which are considered important causes of selection pressures and which probably lead to genetic differentiation between populations (BIERNASKI et al., 2012). From the correlation analysis, there seems to be no established trend in the pattern of seed size, germination and initial growth of seedlings as a function of location, climate and soil characteristics. But, instead as a function of the mother tree characteristic itself, such as height and diameter, which may indicate younger age of the plant in which the collection was made.

\section{CONCLUSIONS}

- It was found the existence of genetic variability among the thirteen mother trees of the study as well as significant differences for all the evaluated characteristics, being the use of the seedlings in areas of forest restoration favorable. 
- Length and width of seeds showed a high value for heritability (above 0.6) and can be used as an indicator of genetic variability of the species.

\section{REFERENCES}

AGUIAR, A. V.; SOUZA, V. A.; SHIMIZU, J. Y.; Seleção genética de progênies de Pinus greggii para formação de pomares de sementes. Pesquisa Florestal Brasileira, Colombo, v. 32, n. 62, p. 107-117, 2010.

BACKES, P.; IRGANG, B. Árvores do Sul: guia de identificação e interesse ecológico. Porto Alegre: Instituto Souza Cruz, 2002, 326 p.

BERTI, C. L. F.; FREITAS, M. L. M.; ZANATTO, A. C. S.; MORAIS, E.; MORAES, M. L. T.; SEBBENN, A. M. Variação genética, herdabilidade e ganhos na seleção para caracteres de crescimento e forma em testes de progênies de polinização aberta de Eucalyptus cloeziana. Revista do Instituto Florestal, São Paulo, v. 23, p. 1326, 2011.

BIERNASKI, F. A.; HIGA, A. R.; SILVA, L. D. Variabilidade genética para caracteres juvenis de progênies de Cedrela fissilis vell.: subsídio para definição de zonas de coleta e uso de sementes. Revista Árvore, Viçosa, v. 36, n. 1, p. 49-58, 2012.

BRANCALION, S. P H.; ISERNHAGEN, I.; GANDOLFI, S.; RODRIGUES, R. R. Plantio de árvores nativas brasileiras fundamentada na sucessão florestal. In: RODRIGUES, R. R.; BRANCALION, S. P. H.; ISERNHAGEN, I. Pacto pela restauração da mata atlântica: referencial dos conceitos e ações de restauração florestal.: São Paulo: Instituto Bio Atlântica ERF/ESALQ, 2009. 256 p.

COSTA, R. B da; RESEND, M. D. V de; GONÇALVES, P de S.; ROA, R. A. R.; FEITOSA, K. C de O. Predição de parâmetros e valores genéticos para caracteres de crescimento e produção de látex em progênies de seringueira. Bragantia, Campinas, v. 69, n. 1, p. 49-56, 2010.

FELIPPI, M.; MAFFRA, C. R. B.; CANTARELLI, E. B.; ARAÚJO, M. M.; LONGHI, S. J. Fenologia, morfologia e análise de sementes de Apuleia leiocarpa (Vogel) J.F Macbr. Ciência Florestal, Santa Maria, v. 22, n. 3, p. 477491,2012

FONTANA, C.; SEVEGNANI, L. Quais são as espécies arbóreas comuns da floresta estacional decidual em Santa Catarina? Revista de estudos ambientais, Blumenau, v.14, n.1, p. 74-88, 2012.

HAMRICK, J. L., GODT, M. J. W. Allozyme diversity in plant species. In: BROWN, A. H. D., CLEGG, M. T., KAHLER, A. L., WEIR, B. S. Plant population genetics, breeding, and genetic resources. Sunderland: Sinauer 1989. $437 \mathrm{p}$.

KAGEYAMA, P. Y.; LEPSCH-CUNHA, N. M. Singularidade da biodiversidade nos trópicos. In: GARAY, I.; DIAS, B. F. S. (Ed). Conservação da biodiversidade em ecossitemas tropicais. Petrópolis: Editora Vozes, 2001, $432 \mathrm{p}$.

KONZEN, E. R. Towards conservation strategies for forest tree endangered species: the meaning of population genetic statistics. Advances Forestry Science, Cuiabá, v. 1, p. 45-51, 2014.

KUBOTA, T. Y. K.; MORAES, M. A.; SILVA, E. C. B.; PUPIN, S.; AGUIAR, A. V.; MORAES, M. L. T.; FREITAS, M. L. M.; SATO, A. S.; MACHADO, J. A. R.; SEBBENN, A. M. Variabilidade genética para caracteres silviculturais em progênies de polinização aberta de Balfourodendron riedelianum (Engler). Scientia Forestalis, Piracicaba, v. 43, n. 106, p. 01-08, 2015 a.

KUBOTA, T. Y. K.; SILVA, E. C. B.; MORAES, M. L. T.; TARAZI, R.; SEBBENN, A. M. Herdabilidade em caracteres de crescimento em populações fragmentadas de Copaifera langsdorffii Desf. (Fabaceae). Scientia Forestalis, Piracicaba, v. 43, n. 105, p. 235-242, 2015 b.

LORENZI, H. Árvores brasileiras: manual de identificação e cultivo de plantas arbóreas nativas do Brasil. Nova Odessa: Instituto Plantarum, v. 1, 2008, 384 p.

MARCHIORI, J. N. C. Dendrologia das angiospermas: leguminosas. Santa Maria: Ed. UFSM, 1997, 200 p.

MENEGATTI, R. D.; MANTOVANI, A.; NAVROSKI, M. C. Parâmetros genéticos para caracteres de crescimento inicial de progênies de bracatinga em Lages, SC. Pesquisa Florestal Brasileira, Colombo, v. 36, n. 87, p. 235-243, 2016. 
NICOLOSO, F. T.; GARLET, A.; ZANCHETTI, F.; SEBEM, E. Efeito de métodos de escarificação na superação da dormência de sementes e de substratos na germinação e no desenvolvimento da grápia (Apuleia leiocarpa). Ciência Rural, Santa Maria, v. 27, n. 3, p. 419-424, 1997.

PÁDUA, G. P.; ZITO, R. K.; ARANTES, N. E.; FRANÇA NETO, J. B. Influência do tamanho da semente na qualidade fisiológica e na produtividade da cultura da soja. Revista Brasileira de Sementes, Londrina, v. 32, n. 3 p. $9-16,2010$.

RESENDE, M. D. V. Delineamento de experimentos de seleção para maximização da acurácia seletiva e do progresso genético. Revista Árvore, Viçosa, v. 19, n. 4, p. 479-500, 1995.

ROSADO, C. C. G.; GUIMARÃES, L. M. da S.; TITON, M.; LAU, D.; ROSSE, L.; RESENDE, M. D. V. de.; ALFENAS, A. C. Resistance to ceratocystis wilt (Ceratocystis fimbriata) in parents and progenies of Eucalyptus grandis x E. urophyll. Silvae Genetica, Varsóvia, v. 59, n. 2, p. 99-106, 2010.

SANT'ANA, V. Z.; FREITAS, M. L. M.; MORAES, M. L. T.; ZANATA, M.; ZANATTO, A. C. S.; MORAES, M. A.; SEBBENN, A. M. Parâmetros genéticos em progênies de polinização aberta de Enterolobium contortisiliquum (Vell.) Morong em Luiz Antonio, SP, Brasil. Hoehnea, São Paulo, v. 40, n. 3, p. 515-520, 2013.

SANTOS, F. S.; PAULA, R. C.; SABONARO, D. Z.; VALADARES, J. Biometria e qualidade fisiológica de sementes de diferentes matrizes de Tabebuia chrysotricha (Mart. Ex A. DC.) StandI. Scientia Forestalis, Piracicaba, v. 37, n. 82, p. 163-173, 2009.

SEBBENN, A. M.; SIQUEIRA, A. C. M. de F.; KAGEYAMA, P. Y.; MACHADO, A. R. Parâmetros genéticos na conservação da Cabreúva - Myroxylon peruiferum L.F. Allemao. Scientia Forestalis, Piracicaba, n. 53, p. 3138, 1998.

THEBALDI, M. S.; LIMA, L. A.; SILVA, A. C.; COLARES, M. F. B.; LIMA, P. L. T. Eficiência de sistemas de irrigação em mudas de espécies florestais nativas produzidas em tubetes. Ciência Florestal, Santa Maria, v. 26, n. 2, p. 401-410, 2016.

VENCOVSKY, R. Herança quantitativa. In: PATERNIANI, E., ed. Melhoramento e produção de milho no Brasil. Piracicaba: Fundação Cargill, 1978, 650 p. 